\title{
Strategic Partnership of Universities and Industrial Enterprises within the Framework of Smart City Construction
}

\author{
Alexander M. Boronachin \\ Head of the Department of laser measurement and \\ navigation systems \\ Saint Petersburg Electrotechnical Univeristy "LETI" \\ St. Petersburg, Russia \\ amboronachin@etu.ru
}

\author{
Dmitrii S. Shevchenko ${ }^{1}$, Anna Y. Glazova ${ }^{2}$ \\ Department of Biomedical Engineering \\ Saint Petersburg Electrotechnical Univeristy "LETI" \\ St. Petersburg, Russia \\ 1dsshevchneko@stud.etu.ru²auglazova@etu.ru
}

\begin{abstract}
Nowadays the issue of strategic management and planning of new urban areas and spaces is acute. This article analyses the cooperation of higher education and urban development companies in the framework of construction of the smart city. An example of closed coexisting system "the developer-city-university" is given below.
\end{abstract}

Keywords - engineering education; competencies; educational process; breakthrough technologies, smart city, smart environment, Internet of things, urban space

\section{INTRODUCTION}

At the moment there is a massive inevitable urbanization of both countries and particular regions. This process is a natural evolutionary path for the development of human society. However with increasing of technology and the emergence of new construction standards, new requirements for the creation of the city as an integrated system, which is capable to satisfy the needs of residents, are appearing. A technically welldesigned city project has many advantages compared to a standard city project: from simplifying economic management to the possibility of unimpeded scaling of the city space and the city's ability to change quickly and adapt to the residents needs at the moment.

\section{CHALlENGE OF URBAN PLANNING COMPANIES STAFFING}

The construction of a smart city involves the implementation of a number of infrastructural transformations connected with the concept of sustainable development. Townplanning companies are tasked with designing cities with a high level of economic competitiveness and a low level of negative impact on residents and the environment. Thus it is necessary for a smart city to meet the following requirements: increasing the general welfare of residents and ensuring economic growth, reducing the environmental load on the occupied area, optimizing management systems, and developing modern approaches to ensuring security. Summing

This research was carried out as part of the governmental project "Scientific-Research Activities (basic scientific research, applied scientific research, and experimental developments)" in the base part of the governmental order from the RF Ministry of Education and Science, project no. 8.6743.2017/8.9. these factors up we can conclude that the maintenance of such staff of diverse specialists within one company is economically costly [1].

One of the options for building a smart city is the construction of this facility from the ground up, with this approach it is possible to avoid many of the problems faced by cities and urban areas that need to be modernized. One such problem is the level of administrative barriers. In the already legally and economically settled urban area the developer has a number of strictly regulated methods for coordinating the project, and the speed of coordination of design and construction activities is one of the important factors. There is an isolation of opinions with creating the infrastructure of the smart district while modernizing the existing municipalities. This factor is due to the fact that representatives of all socioeconomic niches, such as representatives of the administration, business, trade unions, ordinary citizens, are present on the already formed soil in the region. Their relationship should be extremely open and clear, and conflicts of interest should be minimized. During the construction of the district from the ground up it is possible to almost completely minimize conflict situations and speed up decision-making as quickly as possible since the developer bears the bulk of the responsibility.

Another limiting factor in the construction of the "smart district" based on the current municipality may be the underdevelopment or obsolescence of the housing and utility services and the transport system. It is very important to understand that for a modern city that meets all the needs of residents, both transport accessibility and timely solution of housing and utility problems are important. In areas of the city, even within the same district, houses belonging to different management, companies can be located, which creates an additional link in the chain of interaction between social groups within the city and an additional factor of conflicts of interest.

Combining all the factors that should be taken into account when constructing both new and modernizing existing municipalities to the state of a smart city, it can be noted that now the main problem is the lack of labor resources of the relevant qualifications for an individual town-planning company. 
The implementation of the smart city concept involves the use of highly motivated and qualified employees and specialists in relevant fields, ongoing training, inviting the best international and local experts in the field of urban planning, the IT sector, and economic development. They would be ready to solve the problems of transforming the urban environment and respond promptly to changing requests population and environmental changes in the area. High requirements to personnel are also caused by creation of automatic control systems smart area of infrastructure and need of their service [2].

\section{COOPERATION OF HIGH SCHOOLS AND URBAN DEVELOPMENT COMPANIES IN ORDER TO ENSURE HIGH EDUCATIONAL LEVEL}

One of the solutions to the problem of personnel shortage described above is direct and indirect cooperation between urban planning companies and universities. The relationship of these two structures must be built in such a way that the development of the city's infrastructure and educational space is an economically and socially beneficial interaction between the developer and the university.

In Fig. 1, you can consider an example of interaction between the developer, the city and the university.

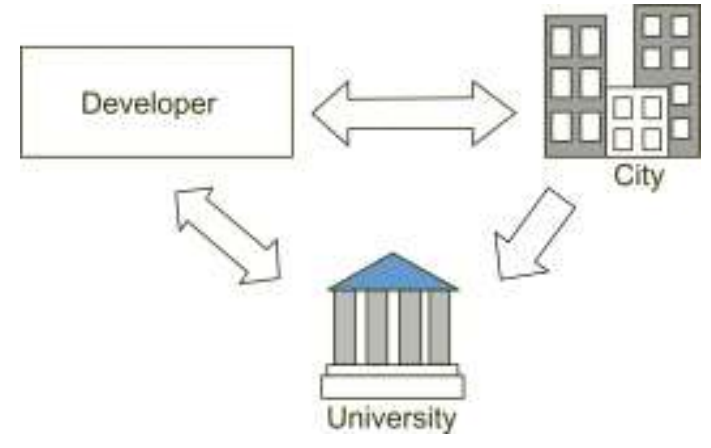

Fig. 1. Scheme of interaction between the developer, the city and the university

The diagram in Fig. 1 illustrates the interaction of the developer, which forms the urban environment and responds to its changes with quality solutions to the tasks. In turn, the city forms the human resource necessary for the existence of higher education institutions. Universities generate highly qualified personnel, which are important for the normal functioning of the urban environment and urban development company, and also help in the development and improvement of smart city systems.

The interaction of the city and the university in a broader sense can be implemented step by step. For example, through the joint efforts of all three stakeholders: the builder, the city and the university, a joint project is being developed to promote schools aimed at early career guidance and the acquisition of certain skills and knowledge by students. Thus, not only the quality of education of a particular educational institution of a secondary school increases, but the overall quality of education in the region as well, the degree of motivation of applicants for admission to a specific higher educational institution increases.

This interaction option can be illustrated by the extended scheme (Fig. 2). The diagram depicted in Fig. 2 illustrates the importance of two-way interaction in the system of directed education between higher education institutions and schools. The creation of cooperation at this level provides the most favorable ground for cooperation: holding joint events, competitions, open days, attending individual lectures and practices, implementing evening school programs for students in school or on vacation. A similar situation is in the bilateral interaction of enterprises with schools and universities. Organization of excursions to enterprises, acquaintance with the profession - these and many other events are aimed primarily at motivating students and additional career guidance, which in the future is beneficial to all participants in the partnership. The industrial enterprise in this scheme is another motivator for schoolchildren and applicants when choosing a profession, for university it is source of additional funding and a science-stimulating factor, for the city it is an executor of creation of infrastructure support.

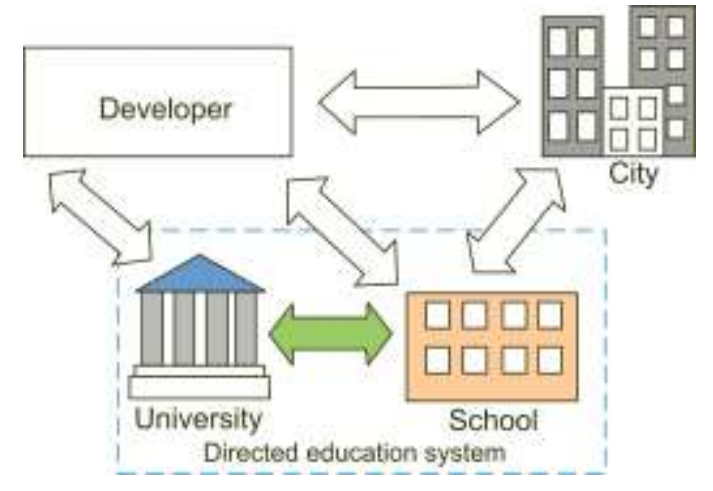

Fig. 2. Scheme of the implementation of the project directed education

\section{NECESSARY SECURITY OF THE DRAFT STRATEGIC PARTNERSHIP}

For the successful implementation of the Smart City project, it is necessary to ensure maximum interaction between the project participants, as well as fulfill the following strategic tasks.

For universities:

- Form and timely update curricula in accordance with the trends of scientific trends;

- Improve the overall quality of education by increasing the state-university-enterprise [2, 3] feedback contacts;

- Ensure maximum transparency during the training of specialists and provide access to employees of enterprises in order to test students' knowledge.

For enterprises:

- Competently carry out financing and cash infusion for the development of educational institutions;

- Participate in a training program for staff; 
- Have an idea and formulate requirements for personnel in their preparation $[4,5]$.

For schools:

- Actively collaborate with universities in order to exchange experience in education;

- Provide additional support to students who are particularly successful in the learning process;

- Provide access to higher education teachers and enterprise workers for the purpose of career guidance and the development of personal qualities of students.

The main management link in this chain should be considered the Ministry of Science and High Education, which quickly responds to the convergence of enterprises and universities and provides more opportunities for the implementation of new educational standards (for example, FSES $3++$ ).

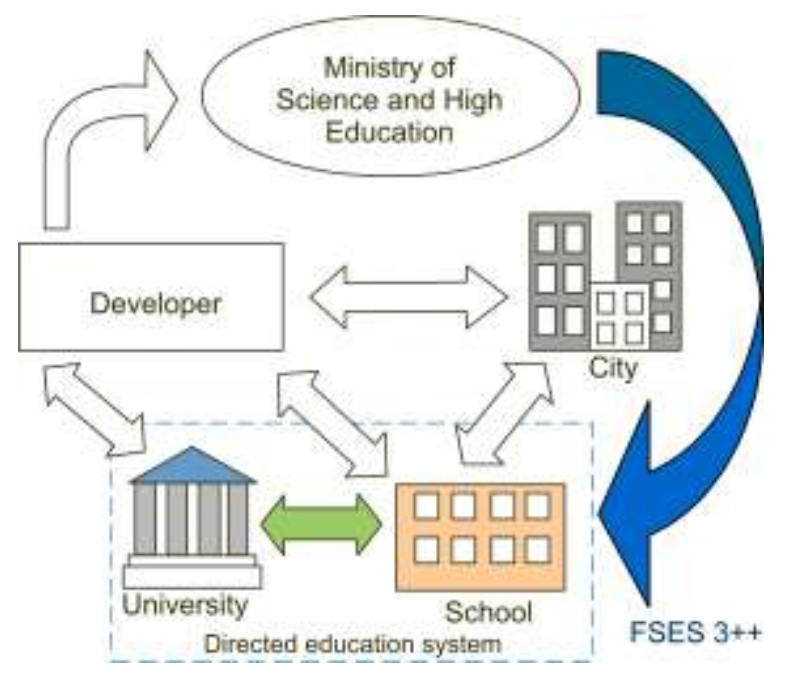

Fig. 3. Scheme of interaction of enterprises with higher educational institutions through federal education standards

Fig. 3 demonstrates the interaction of enterprises (consumers of highly qualified staff) with high schools through a directed education system regulated by the Ministry of Education. The interaction of enterprises and the ministry consists in the timely creation of requests for improving the quality of education and the number of graduates of highly qualified specialists. The Ministry, in turn, forms and implements new educational programs that are aimed at meeting the staff needs of enterprises through the development of directed education systems.

\section{EXAMPLE OF INTERACTION}

One example of successful initiatives is a school project with an educational laboratory based on an educational institution. The laboratory can be equipped and built by attracting funds of the construction company itself, and the direct supervision of the project and the preparation of equipment filling plans will be carried out by the university. Further training of school students in this laboratory and preparation of children for admission to universities is carried out by employees of the university curator and school staff. They can also undergo advanced training on the territory of the university curator.

With a longer interaction, such laboratories become clusters, concentrating within their walls not only students of the same school, but uniting many schools in the district and even the region. An example of the successful implementation of such a project is the Kudrovo Education Center. Extracurricular activities of the laboratory are aimed at developing students' independence in obtaining knowledge, attracting them to environmental activities, and developing environmental skills. Students involved in sections of scientific communities receive knowledge about the nature of the most important physical phenomena of the world; change their attitude to the subject component of many school courses through a change in worldview and the development of high scientific and cultural values. As a result, due to the large motivation, and, as a result, better preparation, students get advantages when entering higher educational institutions. The training program in this laboratory is designed for one academic year and is divided into four main blocks, during the development of which students personally are acquainted with scientific equipment and interact with it. Each training block is dedicated to a separate group of environmental problems that people in their life face constantly.

\section{PROSPECTS FOR THE DEVELOPMENT OF COOPERATION}

Further development of the strategic partnership, carried out by integrating the latest scientific developments of universities at urban enterprises, is possible through the organization of high-tech and environmental infrastructure.

- Organization of separate garbage collection. It is possible to elaborate a system of public facilities and places aimed at creating a convenient and beneficial system for waste sorting and disposal for residents.

- Introduction of alternative energy sources. In gathering places for residents of districts (playgrounds, parks, etc.), it is possible to install various electrical appliances (chargers for mobile devices, lights, heated benches, etc.) that are "powered" from alternative energy sources.

- Organization of monitoring and control systems for the environmental situation in the area.

With appropriate funding, it is possible to develop and implement more ambitious projects, such as:

- Creating an unmanned delivery of goods and mail within the area.

- Organization of video monitoring systems for the presence of parking spaces or video security systems with the ability to predict the deviant behavior of subjects.

\section{CONCLUSIONS}

The creation of educational laboratories on basis of the school under the leadership of high schools leads to increased 
training not only in the subject activities of the laboratory, but also in general subjects required for admission to the university - physics, mathematics, computer science, etc.

Due to additional training, school students can take part in additional career guidance events held by universities and enterprises, take part in the development of small educational projects and the implementation of the Step into Science program. Such cooperation will lead to the accrual of additional points for admission to higher educational institutions.

For universities, the creation of such laboratories will make it possible to accept the most motivated applicants and provide closer contact when working with enterprises.

For enterprises, the implementation of a strategic partnership is to solve social problems and create a positive image of the enterprise.

\section{REFERENCES}

[1] Veselova A.O., Khatskelevich A.N., Yezhova L.S. Prospects for the creation of smart cities in Russia: systematization of problems and directions for their solution. Vestnik Permskogo universiteta. Seriya: Ekonomika [Bulletin of Perm University. Series: Economics]. 2018. V. 13. No. 1, Pp. 75-89 (in Russian)

[2] Lunev R.A., Shcherbakov A.A., Vinogradov L.V. Tools for creating file storage systems using cloud technologies. Vestnik komp'yuternyh $i$ informacionnyh tekhnologij [Bulletin of computer and information technologies]. Moscow: LLC "publishing house "Spectrum", 2013. No. 1. Pp. 30-33 (in Russian)

[3] Boronachin A.M., Tkachenko A.N., Shalymov R.V. Issues of ensuring the quality of the educational process in modern conditions. Materialy konferencii "Informacionnye tekhnologii v upravlenii» (ITU-2018). [Materials of the conference "Information Technologies in Management" (ITU-2018)]. SPb.: JSC Concern Central Research Institute Elektropribor. 2018. Pp. $701-711$ (in Russian)

[4] Chechenina I.V. Problems of management of innovative potential of housing and communal services in the implementation of the concept of "Smart city". Vestnik BGTU im. V.G. Shuhova. [Bulletin of BSTU named after V. G. Shukhov]. 2014. No. 3. Pp. 104-108. (in Russian) 